\title{
PENGARUH KOMPENSASI TERHADAP KINERJA TENAGA HARIAN LEPAS-TENAGA BANTU PENYULUH PERTANIAN (THL-TBPP) PADA BADAN PELAKSANA PENYULUH PERTANIAN, PERIKANAN DAN KEHUTANAN KABUPATEN MUSI BANYUASIN
}

\author{
Muhlisin \\ Ria Novita Restu \\ Sekolah Tinggi Ilmu Ekonomi Rahmaniyah \\ Email : \\ stiermuhlisin@gmail.com \\ ria.restustier@gmail.com
}

\begin{abstract}
Abstrak
This study aims to determine the effect of compensation on the performance of Daily Release Workers - Agricultural Extension Workers (THL-TBPP) at the Implementing Agency for Agricultural, Fisheries and Forestry Extension of Musi Banyuasin Regency, South Sumatra. The research was conducted at Agricultural Extension Agency, Fishery and Forestry Agency of Musi Banyuasin Regency with a total sample of 51. The method of analysis used in the research is simple linear regression, by conducting validity test, reliability test and hypothesis test. The results of this study indicate that the compensation has a positive effect on the performance of the Relevant Force-Tenaga Bantu Penuluh Pertanian (THL-TBPP) with a relationship level of 57.8\%
\end{abstract}

Keywords: compensation, performance, simple linear regression.

\section{PENDAHULUAN}

\section{Latar Belakang}

Kehidupan suatu organisasi secara mendasar adalah sangat ditentukan oleh adanya manusia dan segenap sumber dayanya. Manusialah yang dapat menggerakkan suatu organisasi dengan menghubungkan segenap tenaga, pikiran, bakat, kreativitas dan berupaya demi keberlangsungan kehidupan organisasi tersebut. Manusia adalah sumber daya yang memiliki nilai tertinggi bagi setiap organisasi, karena dapat memberikan manfaat yang besar sekali bila penggunaan tenaga manusia secara tepat guna.

Di samping itu, kinerja karyawan sangat menentukan keberhasilan perusahaan dalam merealisasikan berbagai tujuannya. Hal tersebut disebabkan karena karyawan merupakan orang yang melakukan perencanaan, pengorganisasian, pengarahan, serta melakukan pengendalian terhadap berbagai aktivitas perusahaan. Tanpa adanya karyawan yang kompeten, mustahil perusahaan dapat mencapai tujuannya secara efektif dan efisien. Untuk itu, setiap perusahaan perlu mengoptimalkan kinerja karyawan dalam rangka meningkatkan keunggulan kompetitif perusahaan.

Dalam meningkatkan kinerja karyawannya, perusahaan menempuh beberapa cara misalnya melalui pendidikan, pelatihan, pemberian kompensasi yang layak, menciptakan lingkungan kerja yang kondusif dan pemberian motivasi. Melalui proses-proses tersebut, karyawan diharapkan akan lebih memaksimalkan tanggung jawab atas pekerjaan mereka karena para karyawan akan terbekali oleh pendidikan dan pelatiahan yang tentu berkaitan 
implementasi kerja mereka. Sedangkan pemberian kompensasi, lingkungan kerja yang baik serta pemberian motivasi pada dasarnya merupakan hak para karyawan dan merupakan kewajiban dari pihak perusahaan untuk mendukung kontribusi para karyawannya dalam rangka mencapai tujuan yang telah ditentukan. Untuk menjamin tercapainya keselarasan tujuan, pimpinan organisasi bisa memberikan perhatian dengan memberikan kompensasi karena kompensasi merupakan bagian dari hubungan timbal balik antara organisasi dengan sumber daya manusia.

Pemberian kompensasi sangat dibutuhkan oleh perusahaan maupun guna meningkatkan kinerjanya. Adapun bentuk kompensasi langsung adalah gaji, tunjangan, bonus dan komisi. Sedangkat untuk kompensasi tidak langsung diantaranya pelatihan, wewenangdan tanggung jawab, penghargaan atas kinerja serta lingkungan kerja yang mendukung.

Menurut Panggabean dalam Sutrisno [2009: 54], kompensasi didefinisikan sebagai setiap bentuk penghargaan yang diberikan kepada karyawan sebagai balas jasa (reward) atas kontribusi yang mereka berikan kepada organisasi. Sedangkan Menurut Mangkunegara [2009: 17], "kinerja dapat didefinisikan sebagai hasil kerja secara kualitas dan kuantitas yang dapat dicapai oleh seseorang pegawai dalam melaksanakan tugas sesuai dengan tanggung jawab yang diberikan kepadanya.

Pembangunan pertanian ke depan diharapkan dapat memberikan kontribusi yang lebih besar terhadap peningkatan pertumbuhan perekonomian nasional, penciptaan lapangan kerja bagi penduduk pedesaan, pengurangan kemiskinan, serta pelestarian lingkungan dengan Visi Pertanian 2016, yaitu "Terwujudnya Sistem PertanianBioindustri Berkelanjutan yang Menghasilkan Beragam Pangan Sehat dan Produk Bernilai Tambah Tinggi Berbasis Sumberdaya Lokal untuk Kedaulatan Pangan dan Kesejahteraan Petani”.

Sehubungan dengan kebijakan sektor pertanian tersebut, maka peran penyuluh dalam pembangunan pertanian dewasa ini kian diperlukan dan menempati posisi yang strategis dan menentukan bagi keberhasilan pembangunan. Penyuluh mitra kerja sebagai guru, motivator dan fasilitator, konsultan petani, penganalisis serta pengorganisasian dituntut mampu memberikan: (1) kondisi kondusif sehingga berbagai kegiatan penyuluhan sebagai proses pembelajaran petani berjalan optimal, (2) menjawab tuntutan dan tantangan dalam berbagai hal, (3) menggali dan meningkatkan kemampuan petani dalam memajukan usaha taninya.

Pada era otonomi daerah, secara teoritis memberi ruang inovasi bagi daerah untuk merevitalisasi kinerja penyuluhan pertanian tetapi kinerja penyuluh pertanian rendah. Hal ini disebabkan karena rendahnya pengelolaan sistem penyuluhan, profesionalisisme dan mobilisasi para penyuluh terhambat oleh aturan dan kebijakan pemerintahan setempat, administrasi sistem penyuluh yang hampir tidak ada yang berpihak kepada petani. Kelembagaan penyuluh tidak didukung oleh dana yang memadai, pemerintah daerah cenderung mengalokasikan infrakstruktur yang dapat dilihat secara fisik dibandingkan dengan kegiatan penyuluhan yang hasilnya tidak dapat dilihat seketika itu.

Badan Pelaksana Penyuluh Pertanian, Perikanan, dan Kehutanan Kabupaten Musi Banyuasin sebagai Badan Pelaksana Pelayanan Pertanian sangat bergantung pada kinerja karyawan sebagai roda penggerak dalam perkembangan penyuluhannya. Tenaga Harian Lepas Tenaga Bantu Penyuluh Pertanian (THL-TB Penyuluh Pertanian), mempunyai peranan yang strategis dalam pencapaian 4 (empat) sukses pembangunan pertanian melalui pemberdayaan pelaku utama dan pelaku usaha. Untuk itu, penyuluh pertanian khususnya THL-TB Penyuluh Pertanian sebagai ujung tombak pembangunan pertanian perlu ditingkatkan kompetensinya dalam mengawal program tersebut.

Berdasarkan wawancara yang dilakukan pada Badan Pelaksana Penyuluh Pertanian, Perikanan, dan Kehutanan Kabupaten Musi Banyuasin, kompensasi yang di dapatkan oleh para Tenaga Harian Lepas- Tenaga Bantu Penyuluh Pertanian (THL- 
TBPP) yang berjumlah 51 orang yang tersebar dalam 14 Balai penyuluhan yang bertempat di 14 Kecamatan di antara nya gaji yang diterima dibawah Upah Minimum Regional (UMR) dan hanya dibayar 10 bulan dengan masa kerja 12 bulan. Tenaga Harian Lepas-Tenaga Bantu Penyuluh Pertanian (THL-TBPP) mendapatkan peluang mengikuti pelatihan. Hal ini dilakukan dengan tujuan menciptakan para penyuluh yang profesional dan berkompeten.

Berdasarkan uraian di atas, maka dilakukan penelitian dengan judul "Pengaruh Kompensasi Terhadap Kinerja Tenaga Harian Lepas-Tenaga Bantu Penyuluh Pertanian (THL-TBPP) Pada Badan Pelaksana Penyuluh Pertanian, Perikanan dan Kehutanan Kabupaten Musi Banyuasin”.

\section{KAJIAN PUSTAKA}

\section{Pengertian Kompensasi}

Kompensasi merupakan pengeluaran dan biaya bagi perusahaan. Perusahaan mengharapkan pengeluaran dan biaya kompensasi ini memperoleh imbalan prestasi kerja yang lebih besar dari karyawan supaya perusahaan tersebut mendapat laba yang terjamin.

Kompensasi didefinisikan secara beragam oleh para pakar. Menurut Daft (2003:416), kompensasi merujuk pada: (1) semua pembayaran uang dan (2) semua barang atau komoditi yang digunakan berdasarkan nilai uang untuk memberi imbalan pegawai. Sedangkan menurut Bernadin (2007: 252), kompensasi merujuk pada semua bentuk hasil keuangan dan tunjangan nyata yang diterima pegawai sebagai bagian dari hubungan kerja.

Sementara itu Kreitner dan Kinicki (2008:643), mendefinisikan kompensasi berdasarkan klasifikasinya, yang terdiri dari kompensasi tunai (cash compensation), kompensasi kotor (gross compensation), dan kompensasi bersih (net compensation). Kompensasi tunai adalah imbalan dalam bentuk gaji, bonus tunai, dan insentif jangka pendek. Kompensasi kotor adalah imbalan yang berbentuk biaya penggajian atas semua keuntungan pegawai dan tunjangan baik total maupun kompensasi tunai. Sementara kompensasi bersih adalah imbalan yang digunakan dengan membandingkan imbalan yang dihitung setelah pajak.

Menurut Hasibuan (2009:118), kompensasi adalah semua pendapatan yang berbentuk uang atau barang langsung atau tidak langsung yang diterima karyawan sebagai imbalan jasa yang diberikan pada perusahaan. Sedangkan menurut Mathis (2001: 85), kompensasi adalah semua bentuk upah atau imbalan yang berlaku bagi karyawan dan muncul dari pekerjaan mereka, dan mempunyai dua komponen. Ada pembayaran keuangan langsung dalam bentuk upah, gaji, insentif, komisi dan bonus. Ada pembayaran yang tidak langsung dalam bentuk tunjangan keuangan seperti uang asuransi dan uang liburan yang dibayarkan oleh majikan.

Menurut Schunk dkk (2008: 138), kompensasi adalah suatu penerimaan sebagai suatu imbalan pemberian kerja kepada penerima kerja untuk suatu pekerjaan atau jasa yang dilakukan dan berfungsi sebagai jaminan kelangsungan kehidupan yang layak bagi kemanusiaan dan diniai dalam bentuk uang yang ditetapkan menurut suatu persetujuan, undang-undang peraturan dan dibayarkan atas dasar suatu perjanjian kerja antara pemberi kerja dan penerima kerja. Dan kompensasi langsung merupakan imbalan jasa kepada karyawan yang diterima secara langsung, rutin atau periodik karena yang bersagkutan telah memberi bantuan atau sumbangan untuk mencapai tujuan organisasi.

Dari uraian tersebut dapat dijalankan bahwa kompensasi adalah sesuatu yang diberikan perusahaan kepada karyawan sebagai balas jasa mereka dan kompensai tersebut dapat dinilai dengan uang atau tanpa uang dan mempunyai kecenderungan yang tetap.

Menurut Mathis (2001:91), pemberian kompensasi bertujuan di antaranya: a. Pemenuhan kebutuhan 
Karyawan menerima kompensasi berupa upah, gaji atau bentuk lainnya adalah untuk dapat memenuhi kebutuhan hidupnya sehari-hari atau dengan kata lain, kebutuhan ekonominya. Dengan adanya kepastian menerima upah atau gaji tersebut secara periodik berarti adanya jaminan pengamanan ekonomi bagi dirinya dan keluarganya yang menjadi tanggungannya.

b. Meningkatkan produktivitas kerja

Pemberian kompensasi yang semakin baik akan mendorong karyawan berkerja secara produktif.

c. Memajukan organisasi atau perusahaan.

Semakin berani suatu perusahaan atau organisasi memberikan kompensasi yang tinggi, semakin menunjukan betapa makin suksesnya suatu perusahaan sebab pemberian kompensasi yang tinggi hanya mungkin apabila pendapatan yang digunakan untuk itu makin besar.

d. Menciptakan keseimbangan dan keadilan.

Ini berarti pemberian kompensasi berhubungan dengan persyaratan yang harus dipenuhi oleh karyawan pada jabatan sehingga tercipta keseimbangan antara input (syarat-syarat) dan output.

Sedangkan dalam bukunya Daft (2003:24), tujuan sistem kompensasi dalam suatu organisasi harus diatur agar merupkan sistem yang baik dalam organisasi. Adapun tujuan sistem kompensasi yang baik antara lain yaitu sebagai berikut:

a. Menghargai prestasi kerja

Pemberian kompensasi yang memadai adalah suatu penghargaan organisasi terhadap prestasi kerja para pegawainya.

b. Menjamin keadilan

Dengan adanya sistem kompensasi yang baik akan menjamin adanya keadilan antara pegawai dalam organisasi. Masing-masing pegawai akan memperoleh imbalan yang sesuai dengan tugas, fungsi, jabatan dan prestasi kerjanya.

c. Mempertahankan pegawai

Dengan sistem kompensasi yang baik para pegawai akan lebih betah atau bertahan bekerja pada organisasi itu.

d. Pengendalian biaya

Dengan sistem kompensasi yang baik akan mengurangi seringnya pelaksanaan rekrutmen sebagai akibat dari makin seringnya pegawai yang keluar mencari pekerjaan yang lebih menguntungkan. Hal ini berarti penghematan biaya untuk rekrutmen seleksi calon pegawai baru.

e. Memenuhi peraturan

Sistem administrasi kompensasi yang baik merupakan suatu tuntutan suatu organisasi yang baik dituntut untuk memiliki sistem administrasi kompensasi yang baik.

Adapun fungsi pemberian kompensasi menurut Dharma (2003: 128) antara lain yaitu:

a. Pengalokasian sumber daya manusia secara efisien

Fungsi ini menunjukan bahwa pemberian yang cukup baik pada karyawan yang berprestasi baik akan mendorong para karyawan untuk berkerja lebih baik kearah pekerjaan yang lebih produktif. Dengan kata lain ada kecenderungan para karyawan dapat bergeser atau berpindah dari kompensasinya rendah ketempat kerja yang kompensasinya tinggi dengan cara menunjukan prestasi kerja yang lebih baik.

b. Mendorong stabilitas dan pertumbuhan ekonomi

Sebagai akibat aplikasi dan penggunaan sumber daya manusia dalam organisasi yang bersangkutan secara efisien dan efektif tersebut maka dapat diharapkan bahwa sistem pemberian kompensasi tersebut secara langsung dapat memberikan stabilitas 
organisasi dan secara tidak langsung ikut andil dalam mendorong stabilisasi dan pertumbuhan ekonomi secara keseluruhan.

c. Penggunaan sumber daya manusia secara lebih efisien dan efektif

Dengan pemberian kompensasi yang tinggi kepada karyawan mengandung implikasi bahwa organisasi akan menggunakan tenaga kerja karyawan dengan seefisien mungkin. Sebab dengan cara demikian organisasi yang bersangkutan akan memperoleh keuntungan semaksimal mungkin. Disinilah produktivitas karyawan sangat menentukan.

Sedangkan menurut Schunk dkk (2008: 261), kompensasi memiliki sejumlah fungsi yaitu:

1. Fungsi motivasi

Imbalan diberikan kepada pegawai agar memotivasi kinerjanya dan mendorong kesetiaan dan rasa memiliki.

2. Fungsi pengawasan

Semua imbalan memiliki potensi untuk mengontrol. Imbalan mengontrol perilaku ketika ditujukan pada individu yang menyelesaikan tugas tertentu atau bekerja ditingkat tertentu. Ketika orang melihat imbalan sebagai mengontrol perilakunya (yakin bertindak dengan cara untuk memperoleh imbalan), orang tersebut menganggap tindakannya berasal dari faktor-faktor diluar dirinya (imbalan) dan yang bersangkutan kehilangan rasa penentuan diri. Ketika kemungkinan imbalan tidak lagi berlaku, tidak ada yang mendorong dirinya untuk menggarap aktivitas, jadi kepetingannya akan berkurang.

3. Fungsi informasi

Imbalan juga menyampaikan informasi tentang keahlian atau kemampuan seseorang ketika dihubungkan dengan kinerja atau kemajuan, seperti ketika pimpinan memuji pegawai untuk mempelajari keahlian baru atau memperoleh pengetahuan baru, pengawas memberi pegawai kenaikan upah untuk bekerja diatas standar dan orang tua membelikan anaknya mainan untuk membuat ruangan tetap bersih.

Menurut Panggabean dalam Sutrisno (2009:56), kompensasi dapat dibedakan menjadi dua, yaitu:

1. Kompensasi langsung (Financial) adalah kompensasi yang langsung dirasakan oleh penerimanya, yakni berupa gaji tunjangan, insentif, komisi dan bonus merupakan hak karyawan dan kewajiban perusahaan untuk membayarnya.

a. Gaji adalah jasa yang dibayar secara periodik kepada karyawan tetap serta mempunyai jaminan yang pasti.

b. Tunjangan adalah kompensasi yang diberikan perusahaan kepada para karyawannya, karena karyawannya tersebut dianggap telah ikut berpartisipasi dengan baik dalam mencapai tujuan perusahaan.

c. Insentif adalah kompensasi yang diberikan kepada karyawan tertentu karena keberhasilan prestasinya di atas standar atau mencapai target.

2. Kompensasi Tidak Langsung (Non Financial) adalah kompensasi yang tidak dapat dirasakan secara langsung oleh karyawan, yakni benefit dan services (tunjangan pelayanan). Benefit dan services adalah kompensasi tambahan yang diberikan berdasarkan kebijaksanaan perusahaan terhadap semua karyawan dalam usaha meningkatkan kesejahteraan mereka. Seperti asuransi kesehatan, pengakuan dari atasan, pembagian kerja, pekerjaan sesuai keterampilan, fasilitas dan lingkungan kerja.

Penentuan besarnya kompensasi dipengaruhi oleh beberapa tantangan implikasi ketergantungan yang bisa memaksa departemen manajemen sumber daya manusia untuk melakukan penyesuaian lebih lanjut tentang kebijaksanaan kompensasi perusahaan. Dalam pelaksanaannya kompensasi tidak dapat lepas dari faktor internal dan eksternal 
perusahaan. Hal ini harus diperhatikan oleh perusahaan agar pelaksanaan kompensasi dapat benar-benar berjalan dengan baik sehingga menimbulkan dampak positif bagi perusahaan.

Menurut Hasibuan (2009:127), faktor-faktor yang mempengaruhi kompensasi adalah:

1. Permintaan dan penawaran tenaga kerja

2. Kemampuan dan kesediaan perusahaan

3. Serikat buruh atau organisasi karyawan

4. Posisi jabatan

5. Kondisi perekonomian nasional

6. Produktivitas dan kinerja karyawan

7. Jenis dan sifat pekerjaan

8. Pendidikan dan pengalaman kerja

Supaya sistem kompensasi memiiki dampak signifikan bagi pegawai dan organisasi, diperlukan strategi khusus yang antara lain meliputi:

1. Mengaitkan pujian, pengakuan dan imbalan bukan tunai bagi hasil tertentu;

2. Menjadikan tiap pegawai terlibat aktif dalam perkembangan, pelaksanaan dan perubahan upah bagi kerja sebagai bagian integral dari strategi dasar organisasi (yaitu: mencapai hasil industri terbaik atau kualitas pelayanan);

3. Mendasarkan penentuan insentif pada data kerja obyektif;

4. Meminta semua pegawai terlibat aktif dalam perkembangan, pelaksanaan dan perubahan konsep upah kerja;

5. Mendorong komunikasi dua arah sehingga persoalan dengan rencana insentif akan diketahui sejak awal;

6. Membangun rencana upah bagi kerja di sekitar struktur partisipasi seperti sistem usulan atau siklus kualitas;

7. Memberi imbalan kerja tim dan kerjasama kapan saja;

8. Menjual rencana secara efektif kepada para pengawas dan manajer kelas menengah yang bisa melihat partisipasi pegawai sebagai ancaman terhadap pandangan wewenang tradisional mereka;

9. Jika bonus tunai tahunan diberikan, bayarlah dengan sejumlah uang untuk meningkatkan dampak motivasinya;

10. Uang memotivasi ketika muncul dalm jumlah besar.

\section{Kinerja}

Menurut Mangkunegara (2009:17), "kinerja dapat didefinisikan sebagai hasil kerja secara kualitas dan kuantitas yang dapat dicapai oleh seseorang pegawai dalam melaksanakan tugas sesuai dengan tanggung jawab yang diberikan kepadanya”. Berbagai macam jenis pekerjaan yang dilakukan oleh pegawai tentunya membutuhkan kriteria yang jelas karena masing-masing jenis pekerjaan tentunya mempunyai standar yang berbeda-beda tentang pencapaian hasilnya, semakin rumit jenis pekerjaan maka standar operating procedure yang ditetapkan akan menjadi syarat mutlak yang harus dipatuhi, pegawai yang memiliki komitmen tinggi akan terus berusaha untuk meningkatkan kinerjanya guna mendukung semua tujuan organisasi.

Menurut Hasibuan (2009:93), "prestasi kerja (kinerja) adalah suatu hasil yang dicapai seseorang dalam melaksanakan tugas-tugas yang dibebankan kepadanya yang didasarkan atas kecakapan, pengalaman dan kesungguhan serta waktu. Prestasi kerja merupakan gabungan dari tiga faktor penting yaitu kemampuan dan minat seorang pekerja, kemampuan dan penerimaan atas penjelasan delegasi tugas serta peran dan tingkat motivasi seorang pekerja.

Menurut Effendi (2004:33), kinerja merupakan hasil kerja yang dihasilkan oleh pegawai atau perilaku nyata yang ditampilkan sesuai peranannya dalam organisasi. 
Kinerja juga berarti hasil yang dicapai seseorang baik kualitas maupun kuantitas sesuai dengan tanggungjawab yang diberikan kepadanya. Selain itu kinerja seseorang dipengaruhi oleh tingkat pendidikan, inisiatif, pengalaman kerja, dan motivasi karyawan. Hasil kerja seseorang akan memberikan umpan balik bagi orang itu sendiri untuk selalu aktif melakukan pekerjaannya secara baik dan diharapkan akan menghasilkan mutu pekerjaan yang baik pula. Pendidikan mempengaruhi kinerja seseorang karena dapat memberikan wawasan yang lebih luas untuk berinisiatif dan berinovasi dan selanjutnya berpengaruh terhadap kinerjanya.

Sopiah dalam Handoko (2010:36), menyatakan lingkungan juga bisa mempengaruhi kinerja seseorang. Situasi lingkungan yang kondusif, misalnya dukungan dari atasan, teman kerja, sarana dan prasarana yang memadai akan menciptakan kenyamanan tersendiri dan akan memacu kinerja yang baik. Sebaliknya, suasana kerja yang tidak nyaman karena sarana dan prasarana yang tidak memadai, tidak adanya dukungan dari atasandan banyak terjadi konflik akan memberi dampak negatif yang mengakibatkan kemerosotan pada kinerja seseorang. Sedangkan kinerja karyawan menurut Simamora (2004:12) adalah tingkat hasil kerja karyawan dalam pencapaian persyaratan pekerjaan yang diberikan. Deskripsi dari kinerja menyangkut tiga komponen penting yaitu:

1. Tujuan

Tujuan ini akan memberikan arah dan mempengaruhi bagaimana seharusnyaperilaku kerja yang diharapkan organisasi terhadap setiap personel.

2. Ukuran

Ukuran dibutuhkan untuk mengetahui apakah seorang personel telah mencapai kinerja yang diharapkan, untuk itu kuantitatif dan kualitatif standar kinerja untuk setiap tugas dan jabatan personal memegang peranan penting.

3. Penilaian

Penilaian kinerja reguler yang dikaitkan dengan proses pencapaian tujuan

kinerja setiap personel. Tindakan ini akan membuat personel untuk senantiasa berorientasi terhadap tujuan dan berperilaku kerja sesuai dan searah dengan tujuan yang hendak dicapai.

Manfaat kinerja pegawai antara lain adalah untuk menganalisa dan mendorong efisiensi produksi, untuk menentukan target atau sasaran yang nyata, lalu untuk pertukaran informasi antara tenaga kerja dan manajemen yang berhubungan terhadap masalah-masalah yang berkaitan.

Adapun indikator kinerja karyawan menurut Guritno dan Waridin [2005:64] adalah sebagai berikut :

1. Mampu meningkatkan target pekerjaan

2. Mampu menyelesaikan pekerjaan tepat waktu

3. Mampu menciptakan inovasi dalam menyelesaikan pekerjaan

4. Mampu menciptakan kreativitas dalam menyelesaikan pekerjaan

5. Mampu maminimalkan kesalahan pekerjaan

Menurut Mangkunegara (2009: 67), faktor-faktor yang dapat mempengaruhi pencapaian kinerja adalah:

1. Faktor Kemampuan

Secara psikologis, kemampuan terdiri dari kempuan potensi (IQ) dan kemampuan realita, artinya karyawan yang memiliki IQ yang rata-rata (IQ 110-120) dengan memadai untuk jabatannya dan terampil dalam mengerjakan pekerjaan sehari-hari, maka ia akan lebih mudah mencapai kinerja yang diharapkan. Oleh karena itu karyawan perlu ditempatkan pada pekerjaan yang sesuai keahliannya.

2. Faktor Motivasi

Motivasi terbentuk dari sikap (Attitude) seorang karyawan dalam menghadapi situasi kinerja. Motivasi merupakan kondisi yang menggerakan diri karyawan yang terarah 
untuk mencapai tujuan organisasi. Sikap mental merupakan kondisi mental yang mendorong diri pegawai untuk berusaha mencapai prestasi kerja secara maksimal. Artinya, seorang karyawan harus siap mental, mampu secara fisik, memahami tujuan utama dan target kerja yang akan di capai, mampu memamfaatkan dalam mencapai situasi kerja.

Mangkuprawira (2007:155), menyatakan bahwa kinerja dipengaruhi oleh faktorfaktor sebagai berikut:

a. Faktor personal/individual, meliputi unsur pengetahuan, keterampilan, kemampuan, kepercayaan diri, motivasi dan komitmen yang dimiliki oleh tiap individu karyawan.

b. Faktor Kepemimpinan, meliputi aspek kualitas manejer dan tem leader dalam memberikan dorongan, semangat, arahan dan dukungan kerja kepada karyawan.

c. Faktor Tim, meliputi kualiatas dukungan dan semangat dan semangat yang diberikan oleh rekan dalam satu tim, kepercayaan terhadap sesama anggota tim, kekompakan dan keeratan anggota tim.

d. Faktor Sistem, meliputi sistem kerja, fasilitas kerja atau infrastruktur yang diberikan oleh organisasi, proses organisasi dan kultur kinerja dalam organisasi.

e. Faktor Situasional, meliputi tekanan dan perubahan lingkungan eksternal dan internal.

f. Konflik, meliputi konflik dalam diri individu/konflik peran, konflik antar individu, konflik antar kelompok/organisasi.

Dalam peningkatan kinerja, paling tidak terdapat tujuh langkah yang dapat dilakukan adalah sebagai berikut:

1. Mengetahui adanya kekurangan dalam kinerja dapat dilakukan melalui tiga cara, yaitu:

a Mengidentifikasikan masalah melalui data dan informasi yang dikumpulkan terus-menerus mengenai fungsi-fungsi bisnis

b Mengidentifikasikan melalui pegawai.

c Memperhatikan masalah yang ada

2. Mengenali kekurangan dan tingkat keseriusan.

Untuk memperbaiki langkah tersebut, diperlukan beberapa informasi, antara lain:

a Mengidentifikasikan masalah setepat mungkin.

b Menentukan tingkat keseriusan masalah.

3. Mengidentifikasikan hal-hal yang mungkin menjadi penyebab kekurangan, baik yang berhubungan dengan sistem maupun yang berhubungan dengan pegawai itu sendiri.

4. Mengembangkan rencana tindakan untuk menanggulangi penyebab kekurangan tersebut.

5. Melakukan rencana tindakan tersebut.

6. Melakukan evaluasi apakah masalah tersebut sudah teratasi atau belum.

7. Mulai dari awal, apabila perlu.

\section{Indikator Kinerja}

Menurut Sudarmanto (2009:11), dimensi atau indikator kinerja merupakan aspekaspek yang menjadi tolak ukur dalam menilai kinerja. Ukuran-ukuran dijadikan tolak ukur dalam menilai kinerja. Dimensi ataupun ukuran kinerja sangat diperlukan karena akan bermamfaat bagi banyak pihak. Miner dalam Sudarmanto (2009:12), mengemukakan 4 dimensi yang dijadikan tolak ukur dalam menilai kinerja, yaitu:

1. Kualitas, yaitu: tingkat kesalahan, kerusakan, kecermatan.

2. Kuantitas, yaitu: jumlah pekerjaan yang dihasilkan.

3. Penggunaan waktu dalam berkerja, yaitu tingkat ketidak hadiran, keterlambatan waktu kerja efektif/ jam kerja hilang. 
4. Kerja sama dengan orang lain dalam berkerja.

Menurut Peraturan Menteri Pertanian RI Nomor 5/Permentan/KP.120/7/2007 tanggal 25 Juli 2007 tentang Pedoman Penilaian Penyuluh Pertanian Berprestasi. Penilaian prestasi meliputi:

1. Kegiatan utama penyuluh pertanian

2. Perencanaan program penyuluhan

3. Penyusunan materi penyuluhan

4. Penerapan metode penyuluhan

5. Pengembangan swadaya dan swakarsa petani

6. Pengembangan hubungan kerjasama dengan lembaga pemerintah dan non pemerintah

Pedoman penilaian penyuluh pertanian berprestasi dimaksud untuk memberikan acuan bagi pelaksana yang terlibat dalam penetapan penyuluh pertanian berprestasi. Tujuan penilaian terhadap calon penyuluh pertanian berprestasi adalah memberikan motivasi kepada penyuluh pertanian untuk lebih meningkatkan kinerjanya dalam penyelenggaraan penyuluh pertanian.

\section{METODE PENELITIAN}

\section{Jenis dan Sumber Data}

Jenis data yang digunakan dalam penelitian ini ada dua:

1. Data Primer

Yaitu data yang pertama kali dicatat dan dikumpulkan oleh peneliti. Dalam penelitian ini datadiperoleh dari Kepala dan Pegawai, serta Tenaga Harian Lepas-Tenaga Bantu Penyuluh Pertanian (THL-TBPP) Badan Pelaksana Penyuluhan Pertanian, Perikanan dan Kehutanan Kabupaten MusiBanyuasin dengan metode sebagai berikut:

a. Wawancara (Interview),

Wawancara merupakan teknik pengumpulan data dalam metode survei yang menggunakan pertanyaan secara lisan kepada subyek penelitian. Dengan cara tanya jawab langsung dengan Kepala serta Pegawai Badan Pelaksana Penyuluhan Pertanian, Perikanan dan Kehutanan Kabupaten Musi Banyuasin

\section{b. Kuesioner,}

Metode ini merupakan metode pengumpulan data melalui pertanyaan dari peneliti dan dijawab oleh responden yang dikemukan secara tertulis. Responden dalam hal ini adalah Tenaga Harian Lepas-Tenaga Bantu Penyuluh Pertanian (THL-TBPP) Badan Pelaksana Penyuluhan Pertanian, Perikanan dan Kehutanan Kabupaten MusiBanyuasin.

\section{Data Sekunder}

Yaitu data yang lebih dahulu diperoleh dalam bentuk yang sudah jadi dikumpulkan dan dilaporkan oleh orang atau instansi di luar dari peneliti. Data sekunder ini diperoleh dengan metode sebagai berikut:

a. Dokumentasi

Dokumentasi adalah metode pengumpulan data melalui tentang bersumber dari dokumen dan laporan yang tersedia di perusahaan/lembaga khususnya data yang relevan dengan topik yang diteliti.Dalam penelitian ini berupa sejarah umum Badan Pelaksana Penyuluh Pertanian, Perikanan dan Kehutanan Kabupaten Musi Banyuasin, struktur organisasi, jumlah Tenaga Harian Lepas-Tenaga Bantu Penyuluhan Pertanian (THLTBPP), daftar kompensasi Tenaga harian Lepas-Tenaga bantu Penyuluh Pertanian (THLTBPP) dan tugas serta wewenang dari masing-masing bagian.

b. Studi Kepustakaan

Merupakankegiatan mencari informasi dari sumber-sumber yang ada pada perpustakaan yang bertujuan untuk mengumpulkan data dan informasi dengan bantuan 
bermacam-macam bahan yang ada pada perpustakaan, seperti: buku, dokumen, majalah dan literatur-literatur yang berhubungan dengan penelitian.

\section{Populasi dan Sampel}

Menurut Sugiyono (2004:80), "Populasi adalah wilayah generalisasi terdiri atas obyek/subyek yang mempunyai kualitas dan karakteristik tertentu yang ditetapkan oleh peneliti untuk dipelajari dan kemudian ditarik kesimpulannya". Populasi dalam penelitian ini adalah seluruh Tenaga Harian Lepas-Tenaga Bantu Penyuluh Pertanian (THL-TBPP) Pada Badan Pelaksana Penyuluhan Pertanian, Perikanan dan Kehutanan Kabupaten Musi Banyuasin yang berjumlah 51 orang. Sedangkan sampel dalam penelitian ini seluruh Tenaga Harian Lepas-Tenaga Bantu Penyuluh Pertanian (THL-TBPP) Pada Badan Pelaksana Penyuluhan Pertanian, Perikanan dan Kehutanan Kabupaten MusiBanyuasin yang berjumlah 51 orang tersebar dalam 14 Balai Penyuluhan yang bertempat di14 Kecamatan. Untuk itu teknik pengambilan sampel yang digunakan adalah sampel jenuh. Menurut Sugiyono (2009:89), sampel jenuh adalah teknik pengambilan sampel bila semua anggota populasi digunakan sebagai sampel.

\section{Metode Analisa Data}

Analisis data yang akan digunakan dalam penelitian ini menggunakan SPSS versi 20. Adapun analisis data yang digunakan adalah analisis regresi linear sederhana untuk mengetahui pengaruh kompensasi terhadap kinerja tenaga harian lepas-tenaga bantu penyuluh pertanian itu sendiri, data juga dianalisis statistik dengan menggunakan SPSS versi 20. Pengujian hipotesis pada penelitian dilakukan setelah melakukan analisis regresi linear sederhana. Namun sebelum melakukan analisis regresi sederhana, dilakukan uji linearitas terhadap data yang telah lolos uji validitas. Uji linearitas ini dilakukan untuk mengetahui apakah terjadi penyimpangan linieritas atau tidak. Hubungan linier antara variabel X dan variabel Y dapat dilihat dari nilai Sig. Pada baris deviation from liniarity pada tabel Anova yang lebih besar dari $\alpha$ sebesar 5\%.

Analisis regresi linear sederhana adalah analisis yang hanya berkaitan dengan dua variabel saja, satu disebut variabel independen atau variabel bebas biasanya diberi notasi $\mathrm{X}$, sedangkan variabel satunya disebut sebagai variabel dependen atau variabel terikat yang biasa diberi notasi Y. Regresi linear sederhana mengikuti persamaan dibawah ini:

Dimana :

$$
\mathbf{Y}=\boldsymbol{\alpha}+\mathbf{b} \mathbf{X}+\mathbf{e}
$$

$$
\begin{aligned}
& Y=\text { merupakan variabel terikat (Kinerja Penyuluh) } \\
& \mathrm{X}=\text { sebagai variabel bebas (Kompensasi) } \\
& \mathrm{a}=\text { Konstanta } \\
& \mathrm{b}=\text { Koefisien Regresi yang menunjukan angka peningkatan } \\
& \mathrm{e}=\text { Error term }
\end{aligned}
$$

Selain itu juga akan dilakukan uji linearitas terhadap data yang telah lolos uji validitas. Uji linearitas ini dilakukan untuk mengetahui apakah terjadi penyimpangan linieritas atau tidak. Hubungan yang linier antara variabel $\mathrm{X}$ dan variabel $\mathrm{Y}$ dapat dilihat dari nilai Sig. pada baris deviation from liniarity pada tabel Anova yang lebih besar dari $\alpha$ sebesar 5\%. Sebelum melakukan regresi sederhana dilakukan beberapa uji terhadap instrumen pertanyaan, yaitu:

a. Uji Validitas

Uji validitas digunakan untuk mengukur sah atau valid tidaknya suatu kuesioner. Suatu kuesioner dikatakan valid jika pertanyaan pada kuesioner mampu untuk mengungkapkan sesuatu yang akan diukur oleh kuesioner tersebut. Menurut Ghozali (2005:47), untuk mengukur validitas dapat dilakukan dengan melakukan korelasi antar skor butir pertanyaan dengan total skor konstruk atau variabel. Sedangkan untuk 
mengetahui skor masing-masing item pertanyaan valid atau tidak, maka ditetapkan kriteria statistik sebagai berikut :

1. Jika nilai Sig. (2-tailed) < dari nilai $\alpha=5 \%$ (tingkat kepercayaan 95\%) maka pertanyaan valid dan bisa digunakan untuk penelitian

2. Jika nilai Sig. (2-tailed) $>$ dari nilai $\alpha=5 \%$ (tingkat kepercayaan 95\%) maka pertanyaan tidak valid/di-drop atau tidak digunakan untuk penelitian selanjutnya.

b. Uji Reliabilitas

Menurut Ghozali [2005:48], Uji reliabilitas adalah alat untuk mengukur suatu kuisioner yang mempunyai indikator dari variabel atau konstruk. Suatu kuisioner dinyatakan reliabel atau handal jika jawaban seseorang terhadap pernyataan adalah konsisten atau stabil dari waktu ke waktu. Pengukuran reliabilitas dapat dilakukan dengan dua cara yaitu:

1. Repeted measure atau pengukuran yaitu seseorang akan disodori pertanyaan yang sama pada waktu yang berbeda, dan kemudian dilihat apakah ia tetap konsisten dengan jawabannya.

2. One shot atau pengukuran sekali saja dan kemudian hasilnya dibandingkan dengan pertanyaan yang lain atau mengukur korelasi antara jawaban dengan pertanyaan. Suatu konstruk atau variabel dikatakan reliabel jika memberikan nilai Cronbanch Alpha $>0,60$.

c. Pengujian Hipotesis

Hipotesis dalam penelitian menggunakan analisis regresi linear sederhana. Kriteria yang digunakan untuk hipotesis tersebut adalah:

$\mathrm{H}_{0}$ : Kompensasi tidak berpengaruh signifikan terhadap kinerja Tenaga Harian Lepas-Tenaga Bantu Penyuluh Pertanian (THL-TBPP) Pada Badan Pelaksana Penyuluh Pertanian, Perikanan dan Kehutanan Kabupaten Musi Banyuasin

Ha: Kompensasi berpengaruh signifikan terhadap kinerja Tenaga Harian LepasTenaga Bantu Penyuluh Pertanian (THL-TBPP) Pada Badan Pelaksana Penyuluh Pertanian, Perikanan dan Kehutanan Kabupaten Musi Banyuasin.

Kriteria penilaian:

a. Apabila nilai konstanta /probabilitasnya $>$ taraf nyatanya $(\alpha=0,05)$, maka Ho diterima dan Ha ditolak

b. Apabila nilai konstanta/probabilitasnya $<$ taraf nyatanya $(\alpha=0,05)$, maka Ha diterima dan Ho ditolak.

\section{HASIL DAN PEMBAHASAN}

\section{Uji Validitas}

Uji validitas digunakan untuk mengukur derajat ketepatan dalam penelitian. Perhitungan dilakukan dengan menggunakan bantuan program SPSS, dimana analisis hasil dapat dilakukan dengan menggunakan metode Bivariate Pearson (Pearson product moment correlation) yaitu dengan cara mengkorelasikan masing-masing skor item dengan skor keseluruhan item. Skor keseluruhan item yaitu hasil penjumlahan dari keselurhan item. Item-item yang berkorelasi signifikan dengan skor total menunjukkan item-item tersebut mampu memberikan dukungan dalam ungkapan apa yang inginkan diungkapkan. Hasil dari uji validitas kuesioner X (Kompensasi) dan Y (kinerja) dapat dilihat pada tabel 1 . 
Tabel 1

Hasil Uji Validitas Butir Kuesioner

\begin{tabular}{|c|c|c|c|c|c|c|}
\hline No. & $\begin{array}{c}\text { Butir } \\
\text { Dalam } \\
\text { Kuesioner }\end{array}$ & $\begin{array}{c}\text { Koefisien } \\
\text { Korelasi } \\
\quad(\mathbf{r})\end{array}$ & $\begin{array}{c}\text { Nilai } \\
\text { Kritis } \\
\text { (r-tabel) }\end{array}$ & $\begin{array}{c}\text { Sig. } 2 \\
\text { tailed } \\
\text { (p level) }\end{array}$ & $\begin{array}{l}\text { TarafSig. } \\
(\alpha=\mathbf{0 , 0 5})\end{array}$ & Keterangan \\
\hline 1. & $\mathrm{X} 1$ & 0,755 & 0,271 & 0,000 & 0,05 & Valid \\
\hline 2. & $\mathrm{X} 2$ & 0,798 & 0,271 & 0,000 & 0,05 & Valid \\
\hline 3. & $\mathrm{X} 3$ & 0,794 & 0,271 & 0,000 & 0,05 & Valid \\
\hline 4. & $\mathrm{X} 4$ & 0,484 & 0,271 & 0,000 & 0,05 & Valid \\
\hline 5. & $\mathrm{X} 5$ & 0,747 & 0,271 & 0,000 & 0,05 & Valid \\
\hline 6. & $\mathrm{X} 6$ & 0,787 & 0,271 & 0,000 & 0,05 & Valid \\
\hline 7. & $\mathrm{X} 7$ & 0,739 & 0,271 & 0,000 & 0,05 & Valid \\
\hline 8. & $\mathrm{X} 8$ & 0,761 & 0,271 & 0,000 & 0,05 & Valid \\
\hline 9. & X9 & 0,640 & 0,271 & 0,000 & 0,05 & Valid \\
\hline 10. & $\mathrm{X} 10$ & 0,826 & 0,271 & 0,000 & 0,05 & Valid \\
\hline 11. & $\mathrm{X} 11$ & 0,809 & 0,271 & 0,000 & 0,05 & Valid \\
\hline 12. & $\mathrm{X} 12$ & 0,802 & 0,271 & 0,000 & 0,05 & Valid \\
\hline No. & $\begin{array}{c}\text { Butir } \\
\text { Dalam } \\
\text { Kuesioner } \\
\end{array}$ & $\begin{array}{c}\text { Koefisien } \\
\text { Korelasi } \\
(\mathbf{r}) \\
\end{array}$ & $\begin{array}{c}\text { Nilai } \\
\text { Kritis } \\
\text { (r-tabel) }\end{array}$ & $\begin{array}{c}\text { Sig. } 2 \\
\text { tailed } \\
\text { (p level) }\end{array}$ & $\begin{array}{l}\text { TarafSig. } \\
(\alpha=0,05)\end{array}$ & Keterangan \\
\hline 13. & $\mathrm{X} 13$ & 0,789 & 0,271 & 0,000 & 0,05 & Valid \\
\hline 14. & $\mathrm{Y} 1$ & 0,775 & 0,271 & 0,000 & 0,05 & Valid \\
\hline 15. & $\mathrm{Y} 2$ & 0,769 & 0,271 & 0,000 & 0,05 & Valid \\
\hline 16. & $\mathrm{Y} 3$ & 0,724 & 0,271 & 0,000 & 0,05 & Valid \\
\hline 17. & $\mathrm{Y} 4$ & 0,548 & 0,271 & 0,000 & 0,05 & Valid \\
\hline 18. & Y5 & 0,521 & 0,271 & 0,000 & 0,05 & Valid \\
\hline 19. & Y6 & 0,536 & 0,271 & 0,000 & 0,05 & Valid \\
\hline 20. & $\mathrm{Y7}$ & 0,458 & 0,271 & 0,000 & 0,05 & Valid \\
\hline 21. & Y8 & 0,604 & 0,271 & 0,000 & 0,05 & Valid \\
\hline 22. & Y9 & 0,686 & 0,271 & 0,000 & 0,05 & Valid \\
\hline 23. & Y10 & 0,443 & 0,271 & 0,000 & 0,05 & Valid \\
\hline 24. & Y11 & 0,787 & 0,271 & 0,000 & 0,05 & Valid \\
\hline 25. & Y12 & 0,401 & 0,271 & 0,000 & 0,05 & Valid \\
\hline 26. & Y13 & 0,649 & 0,271 & 0,000 & 0,05 & Valid \\
\hline 27. & Y14 & 0,631 & 0,271 & 0,000 & 0,05 & Valid \\
\hline 28. & Y15 & 0,564 & 0,271 & 0,000 & 0,05 & Valid \\
\hline 29. & Y16 & 0,513 & 0,271 & 0,000 & 0,05 & Valid \\
\hline 30. & Y17 & 0,530 & 0,271 & 0,000 & 0,05 & Valid \\
\hline 31. & Y18 & 0,496 & 0,271 & 0,000 & 0,05 & Valid \\
\hline
\end{tabular}

Sumber : data primer yang telah diolah, 2016

Dari hasil uji validitas diatas, dapat diketahui bahwa semua item dapat dikatakan valid. Dengan cara membandingkan nilai $r$ hitung dengan $r$ tabel. Dengan kriteria pengujian $r$ hitung $>r$ tabel. Nilai $r$ tabel dengan $n=51$ pada signifikanasi 5\% adalah sebesar 0,271. Maka dapat dikatakan nilai $r$ hitung keseluruhan item lebih besar dari $r$ tabel. Sehingga dapat digunakan untuk mengukur instrumen dalam penelitian.

2. Uji Reliabilitas 
Uji reliabilitas adalah indeks yang menunjukkan sejauh mana alat pengukur dapat dipercaya atau diandalkan. Untuk menguji kehandalan variabel dari item dari masingmasing dimensi dilakukan uji reliabilitas dengan nilai koefisien reliabilitas (alpha) > 0,6. Adapun hasil uji reliabilitas yang dilakukan terhadap instrumen penelitian ini dapat dijelaskan pada tabel berikut ini:

Tabel 2

Hasil Uji Reliabilitas Butir Kuesioner

\begin{tabular}{|c|c|c|c|}
\hline No. & $\begin{array}{c}\text { Butir Dalam } \\
\text { Kuesioner }\end{array}$ & Nilai Alpha & Status \\
\hline 1. & $\mathrm{X}$ & 0,935 & Reliabel \\
\hline 2. & $\mathrm{Y}$ & 0,890 & Reliabel \\
\hline
\end{tabular}

Sumber: data primer yang telah diolah, 2016

Dari hasil pengolahan data didapat koefisien reliabilitas (alpha) X (kompensasi) sebesar 0,935 dapat dikatakan reliabel atau terpercaya sebagai alat pengumpulan data dalam penelitian karena lebih besar dari 0,6. Sedangkan untuk koefisien reliabilitas (alpha) Y (kinerja) sebesar 0,890 juga dapat dikatakan reliabel atau terpercaya sebagai alat pengumpulan data dalam penelitian karena lebih besar dari 0,6.

3. Analisis data dan Hasil Penelitan

a. Analisis Regresi

Analisis yang digunakan dalam penelitian ini adalah analisis regresi linear sederhana. Analisis regresi linear sederhana adalah sebuah pendekatan yang digunakan untuk mendefinisikan hubungan linear antara satu variabel prediktor (independent) dan satu variabel respon (dependent).

Berdasarkan hasil dari analisis regresi linear sederhana dengan bantuan program SPSS dapat dilihat pada tabel 3:

Tabel 3

Ringkasan Hasil Regresi Linear Sederhana

Coefficients $^{\mathrm{a}}$

\begin{tabular}{|c|c|c|c|c|c|c|}
\hline \multirow{2}{*}{\multicolumn{2}{|c|}{ Model }} & \multicolumn{2}{|c|}{ Unstandardized Coefficients } & $\begin{array}{c}\text { Standardized } \\
\text { Coefficients }\end{array}$ & \multirow[b]{2}{*}{$\mathrm{t}$} & \multirow[b]{2}{*}{ Sig. } \\
\hline & & B & Std. Error & Beta & & \\
\hline \multirow[t]{2}{*}{1} & (Constant) & 25.796 & 4.292 & & 6.011 & .000 \\
\hline & kompensasi & .959 & .073 & .782 & 13.104 & .000 \\
\hline
\end{tabular}

a. Dependent Variable: kinerja

Sumber : data primer yang telah diolah, 2016

Dari hasil tersebut apabila ditulis dalam bentuk standardized dari persamaan regresinya adalah sebagai berikut

$$
Y=25,796+0,959 X
$$

Keterangan:

$\mathrm{Y}=$ Kinerja

$\mathrm{a}=$ Konstanta

$\mathrm{b}=$ Koefesien regresi

$\mathrm{X}=$ Kompensasi 
Hasil dari persamaan regresi diatas dapat dijelaskan sebagai berikut:

1. Nilai konstanta sebesar 25,976 menyatakan bahwa jika kompensasi (X) nilainya adalah 0, maka nilai kinerja (Y) adalah 19,798.

2. Koefesien regresi untuk kompensasi (X) sebesar 0,959 menyatakan bahwa setiap penambahan satu nilai kompensasi $(\mathrm{X})$, maka nilai kinerja $(\mathrm{Y})$ bertambah sebesar 0,959X.

b. Analisis Korelasi

Analisis korelasi yang digunakan dalam penelitian ini adalah analisis korelasi sederhana. Analisis korelasi sederhana merupakan suatu teknik statistik yang dipergunakan untuk mengukur kekuatan hubungan dua variabel dan juga untuk mengetahui bentuk hubungan antara dua variabel tersebut.

Menurut Sugiyono [2007:14], pedoman untuk memberikan interprestasi koefisien korelasi sebagai berikut:

- $\quad 0,00-0,199=$ sangat rendah

- $\quad 0,20-0,399=$ rendah

- $\quad 0,40-0,599=$ sedang

- $\quad 0,60-0,799=$ kuat

- $\quad 0,80-1,000=$ sangat kuat

\section{Tabel 4}

Ringkasan Hasil Korelasi

Model Summary

\begin{tabular}{|c|c|c|c|c|}
\hline Model & $\mathrm{R}$ & R Square & Adjusted R Square & $\begin{array}{c}\text { Std. Error of the } \\
\text { Estimate }\end{array}$ \\
\hline 1 & $.782^{\mathrm{a}}$ & .578 & .473 & 2.53889 \\
\hline
\end{tabular}

a. Predictors: (Constant), kompensasi

Sumber: data primer yang telah diolah, 2016

Dari hasil perhitungan statistik diatas diketahui nilai korelasi (R) sebesar 0,782, hal ini menunjukkan terjadinya hubungan yang kuat antara kompensasi dan kinerja.

Berdasarkan hasil perhitungan analisis determinasi diketahui bahwa $R$ square $\left(\mathrm{R}^{2}\right)$ sebesar 0,578 atau sebesar 57,8\% kompensasi mempengaruhi kinerja tenaga kerja Harian Lepas-Tenaga Bantu Penyuluh Pertanian (THL-TBPP) pada Badan Pelaksana Penyuluhan Pertanian, Perikanan dan Kehutanan Kabupaten Musi Banyuasin sedangkan sebesar $42,2 \%$ dipengaruhi oleh variabel lain yang tidak dimasukkan kedalam penelitian ini.

4. Uji Hipotesis (Uji t)

Uji Hipotesis (uji t) digunakan untuk menguji kebenaran hipotesis, apakah hipotesis dari penelitian diterima atau ditolak.

Dengan Hipotesis yang diujikan sebagai berikut:

- Ho : tidak ada pengaruh kompensasi terhadap kinerja Tenaga Kerja Kerja Harian Lepas-Tenaga Penyuluh Pertanian (THL-TBPP) pada Badan Pelaksanaan Penyuluh Pertanian, Perikananan dan Kehutanan Kabupaten Musi Banyuasin.

- Ha : ada pengaruh kompensasi terhadap kinerja Tenaga Kerja Kerja Harian Lepas-Tenaga Penyuluh Pertanian (THL-TBPP) pada Badan Pelaksanaan Penyuluh Pertanian, Perikananan dan Kehutanan Kabupaten Musi Banyuasin. 
Dengan kriteria pengujian Ho ditolak dan Ha diterima jika nilai t hitung $>\mathrm{t}$ tabel.

Tabel 5

Tabel Uji t

Coefficients $^{\mathrm{a}}$

\begin{tabular}{|c|c|c|c|c|c|c|}
\hline \multirow{2}{*}{\multicolumn{2}{|c|}{ Model }} & \multicolumn{2}{|c|}{ Unstandardized Coefficients } & $\begin{array}{l}\text { Standardized } \\
\text { Coefficients }\end{array}$ & \multirow[b]{2}{*}{ t } & \multirow[b]{2}{*}{ Sig. } \\
\hline & & B & Std. Error & Beta & & \\
\hline \multirow[t]{2}{*}{1} & (Constant) & 25.796 & 4.292 & & 6.011 & .000 \\
\hline & kompensasi & .959 & .073 & .782 & 13.104 & .000 \\
\hline
\end{tabular}

a. Dependent Variable: kinerja

Sumber: data primer yang telah diolah, 2016

Berdasarkan tabeldiatas diketahui bahwa nilai t hitung sebesar 13,104. Nilai t tabel untuk $\mathrm{n}=51$ sebesar 1,675. Dengan membandingkan $\mathrm{t}$ hitung dengan $\mathrm{t}$ tabel diperoleh bahwa 13,104 lebih besar dari 1,675. Maka dapat disimpulkan bahwa ada pengaruh kompensasi terhadap kinerja Tenaga Kerja Kerja Harian Lepas-Tenaga Penyuluh Pertanian (THL-TBPP) pada Badan Pelaksanaan Penyuluh Pertanian, Perikananan dan Kehutanan Kabupaten Musi Banyuasin.

\section{SIMPULAN DAN SARAN}

\section{Simpulan}

Berdasarkan dari permasalahan yang dibahas maka dapat disimpulkan bahwa:

1. Berdasarkan hasil uji validitas keseluruhan butir kuesioner kompensasi (X) dan kinerja (Y) bernilai valid, karena keseluruhan nilai butir kuesioner kompensasi (X) dan kinerja (Y) besar dari t tabel sebesar 0,271.

2. Berdasarkan hasil uji reliabilitas butir kuesioner kompensasi (X) dan kinerja (Y) dapat dikatakan reliabel karena koefisien reliabilitas untuk kompensasi (X) sebesar 0,935 dan koefisien reliabilitas untuk kinerja (Y) sebesar 0,890 lebih besar dari 0,6.

3. Kompensasi berpengaruh positif terhadap kinerja berdasarkan hasil regresi yaitu : $\mathrm{Y}=25,976+0,959 \mathrm{X}$

Dengan penjelasan sebagai berikut :

a. Nilai konstanta sebesar 25,976 menyatakan bahwa jika kompensasi (X) nilainya adalah 0, maka nilai kinerja (Y) adalah 25,976.

b. Koefesien regresi untuk kompensasi (X) sebesar 0,959 menyatakan bahwa setiap penambahan satu nilai kompensasi $(\mathrm{X})$, maka nilai kinerja $(\mathrm{Y})$ bertambah sebesar $0,959 X$.

4. Berdasarkan perhitungan korelasi besar pengaruh kompensasi (X) dan kinerja (Y) adalah 0,782 yang berarti mempunyai hubungan yang kuat karena berada pada kisaran 0,60-0,799.

5. Berdasarkan perhitungan analisis determinasi diperoleh bahwa $R$ square $\left(\mathrm{R}^{2}\right)$ sebesar 0,578 atau sebesar $57,8 \%$ kinerja dipengaruhi oleh kompensasi sedangkan sisanya sebesar 0,422 atau 42,2\% dipengaruhi oleh variabel lain yang tidak dimasukan dalam penelitian ini seperti disiplin kerja, efektivitas kerja, lingkungan kerja dan lainnya.

6. Berdasarkan perhitungan uji t diperoleh 13,104 >1,1675. Maka Ha diterima dan Ho ditolak, berarti ada pengaruh kompensasi (X) dan kinerja (Y) Tenaga Harian LepasTenaga Bantu Penyuluh Pertanian (THL-TBPP) pada Badan Pelaksana Penyuluh Pertanian, Perikananan dan Kehutanan Kabupaten Musi Banyuasin. 
7. Berdasarakan beberapa analisis data yang telah dilakukan dapat diketahui bahwa Kompensasi berpengaruh positif terhadap Kinerja dengan tingkat hubungan yang kuat, pengaruh tersebut yaitu sebesar 57,8\% dengan persamaan $\mathbf{Y}=\mathbf{2 5 , 9 7 6 + 0 , 9 5 9 X}$.

\section{Saran}

Ada beberapa saran yang perlu diperhatikan sehubungan dengan penelitian ini yaitu :

1. Kepada Badan Pelaksanaan penyuluhan Pertanian, Perikanan dan Kehutanan Kabupaten Musi Banyuasin harus memperhatikan kompensasi yang diberikan dengan cara mengkaji kembali kompensasi yang diberikan apakah sudah sesuai dengan beban kerja yang diberikan.

2. Dalam sistem kompensasi Badan Pelaksanaan penyuluhan Pertanian, Perikanan dan Kehutanan Kabupaten Musi Banyuasin harus memperhatikan kompensasi lain selain gaji yang diberikan secara seksama apakah sesuai dengan tingkat kinerjanya.

3. Badan Pelaksanaan penyuluhan Pertanian, Perikanan dan Kehutanan Kabupaten Musi Banyuasin harus memperhatikan faktor lain yang dapat mempengaruhi kinerja pegawainya khususnya Tenaga harian Lepas-Tenaga Bantu Penyuluh Pertanian (THL-TBPP) agar dapat melaksanakan pelayanan kepada masyarakat dengan optimal.

4. Badan Pelaksanaan penyuluhan Pertanian, Perikanan dan Kehutanan Kabupaten Musi Banyuasin harus memberikan peluang kepada Tenaga harian Lepas-Tenaga Bantu Penyuluh Pertanian (THL-TBPP) untuk mengikuti pelatihan agar menciptakan para penyuluh yang profesional dan berkompeten.

\section{DAFTAR PUSTAKA}

Bernadin, H.J. 2007. Human ResourcesManagement : Anexperiential Approach, Fourth Edition, terjemahan Wibowo. USA : McGraw Hill International.

Daft, Richard L. 2003. ManajemenSumberDayaManusia. Terjemahan Edwar Tanujaya. Jakarta. Penerbit Erlangga.

Dharma. 2003. Menajemen sumber Daya Manusia. Jakarta: Elek Media Komputindo.

Effendi, Harianja Marihot Tua. 2004. Manajemen Sumber Daya Manusia. Jakarta: PT. Gramedia Widiarsana.

Ghozali, Imam. 2005. Aplikasi Analisis Multivariate Dengan Program SPSS. Edisi Ketiga, Badan Penerbit Universitas Diponegoro, Semarang.

Guritno, Bambang dan Waridin. 2005. Pengaruh Persepsi Karyawan Mengenai Perilaku Kepemimpinan, Kepuasan Kerja dan Motivasi Terhadap Kinerja. JRBI.pp. $56-62$.

Handoko, T. Hani. 2010. Manajemen Personalia dan Sumber Daya Manusia. Edisi Kedua. Yogyakarta: BPFE UGM.

Hasibuan, M.S.P. 2009.Manajemen Sumber Daya Manusia (Edisi Revisi). Jakarta. PT. Bumi Aksara.

Kadarisman, M. 2012. Manajemen Kompensasi. Jakarta: Rajagrafindo Persada.

Kreitner dan Kinicki. 2008. Organization behavior 8th edition. Terjemahan Erly Suandy. USA McGrow Hill International Edition.

Mangkunegara. 2009. Evaluasi Kinerja. Bandung: Refika Aditama.

Mangkuprawira, Sjafri. 2007. Manajemen Mutu Sumber Daya Manusia. Bogorr: Ghalia Indonesia.

Mathis, R. 2001. Human Rasources Development (Track MBA series/terjemahan). Terjemahan Jimmy Sadeli dan Bayu Prawira. Jakarta: Prestasi Pustaka.

Peraturan Menteri Pertanian RI Nomor 5/Permentan/KP.120/7/2007 tentang Pedoman Penilaian Penyuluh Pertanian Berprestasi. 
Rivai, Veitzal dan Basri. 2009. Performance Appraisal: Sistem Yang Tepat Untuk Menilai Kinerja Karyawan Dan Meningkatkan Daya SaingPerusahaan. Jakarta. Raja Grafindo Persada.

Schunk dkk. 2008. Organization behaviour USA: McGrow Hill International Edition.

Simamora, Henry. 2004. Manajemen Sumber Daya Manusia. Yogyakarta: SIE YKPN.

Sudarmanto. 2009. Kinerja dan Pengembangan Kompetensi SDM Teori, Dimensi dan Implementasi dalam Organisasi. Yogyakarta: Pustaka Pelajar.

Sugiyono. 2004. Statistika untuk penelitian. Bandung: CV. Alfabeta.

.2009. Metode Penelitian Kuantitatif dan Kualitatif. Bandung: CV Alfabeta.

Sutrisno, Edy. 2009. Manajemen Sumber daya Manusia. Edisi Pertama. Cetakan Pertama. Jakarta: Penerbit Kencana 